Julian Barnes

\title{
PETER CHILDS
}

\section{MANCHESTER 1824}

Manchester University Press 


\section{Julian Barnes}

\section{MANCHESTER 1824}

Manchester University Press 


\section{Contemporary British Novelists}

Series editor Daniel Lea

already published

J. G. Ballard Andrzej Gasiorek

Pat Barker John Brannigan

A. S. Byatt Alexa Alfer and Amy J. Edwards de Campos

Jim Crace Philip Tew

James Kelman Simon Kővesi

lain Sinclair Brian Baker

Graham Swift Daniel Lea

Irvine Welsh Aaron Kelly

Jeanette Winterson Susana Onega 


\section{Julian Barnes}

\section{Peter Childs}

Manchester University Press

Manchester 


\section{Copyright (C) Peter Childs 20II}

The right of Peter Childs to be identified as the author of this work has been asserted by him in accordance with the Copyright, Designs and Patents Act I988.

Published by Manchester University Press

Altrincham Street, Manchester Mi 7JA, UK

www.manchesteruniversitypress.co.uk

British Library Cataloguing-in-Publication Data

A catalogue record for this book is available from the British Library

Library of Congress Cataloging-in-Publication Data applied for

ISBN 978 ० 7190 8Io6 4 hardback

First published 20II

The publisher has no responsibility for the persistence or accuracy of URLs for any external or third-party internet websites referred to in this book, and does not guarantee that any content on such websites is, or will remain, accurate or appropriate.

Typeset Io/I2pt FFScala by Graphicraft Limited, Hong Kong 